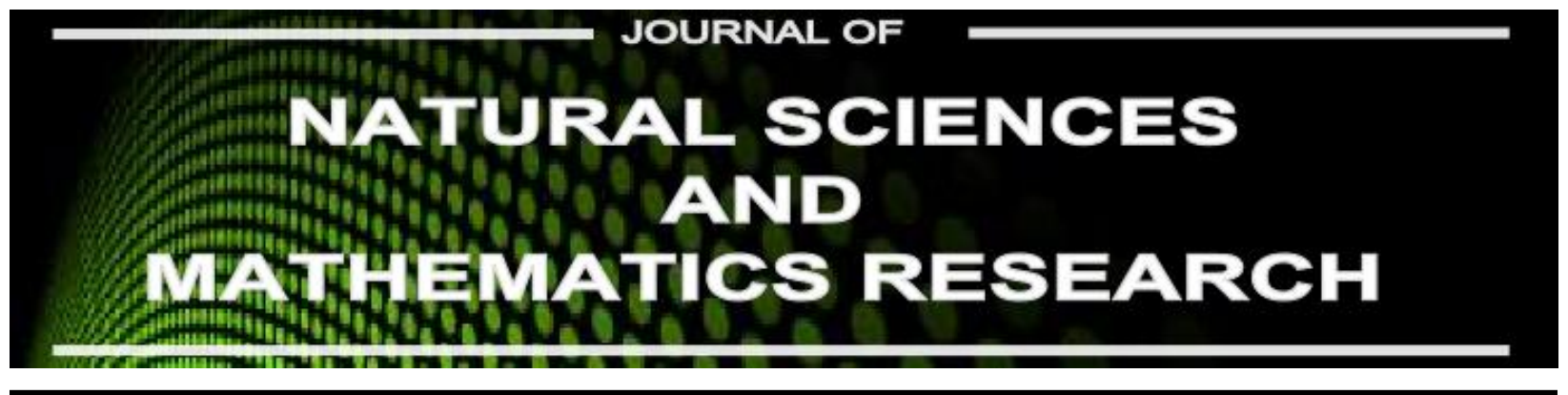

Available online at http://journal.walisongo.ac.id/index.php/jnsmr

\title{
Effect of Thickness on Thermal Conductivity Based on Waste Newspaper Particle Board
}

\section{Yoan Theasy ${ }^{1}$, Agus Yulianto ${ }^{2}$ and Budi Astuti ${ }^{3}$}

${ }_{1}^{1}$ Postgraduate Program Physics Education, State University of Semarang, Bendan Ngisor Semarang 50233.

${ }^{2}$ Department of Physics, Universitas Negeri Semarang, Semarang State University, Campus Sekaran Gunungpati, Semarang, Central Java, Indonesia.

Corresponding author: yoante321@gmail.co.id Recived: 25 April 2017, Revised : 30 May 2017 Accepted: 25 June 2017.

\begin{abstract}
s
Waste newspaper by most people still considered as waste that has not been used optimally, and it is the one of processed materials from wood which has lignocellulose. The material has the potential to produce particle board to test the value of thermal conductivity, which it is expected to be used as heat insulator. The process of producing particle board is by mixing 450 grams pureed newspaper with 260 grams PVAC, then print it with size $(12 \times 7) \mathrm{cm}^{2}$ with the thickness of $0.5 \mathrm{~cm} ; 1 \mathrm{~cm} ; 1.5 \mathrm{~cm} ; 2 \mathrm{~cm} ; 2.5 \mathrm{~cm} ; 3 \mathrm{~cm}$. The process to make particle board drying is for 5 days and the test of thermal conductivity using a 100 watt heat source, and an infrared thermometer. The result obtained from the value of thermal conductivity from newspaper particle board is when more higher value of particle board thickness then more higher the thermal conductivity value. From these result it can be concluded that the particle board which can be used as heat insulation material is the one that has a thermal conductivity value of $0.066 \mathrm{~W} / \mathrm{m}^{\circ} \mathrm{C} ; 0.125 \mathrm{~W} / \mathrm{m}^{\circ} \mathrm{C} ; 0.0167 \mathrm{~W} / \mathrm{m}^{\circ} \mathrm{C}$ with thickness range of $1 \mathrm{~cm}$ to $2 \mathrm{~cm}$.C2017 JNSMR UIN Walisongo. All rights reserved.
\end{abstract}

Key words: Newspaper; PVAC; Particle Board; Thermal Conductivity.

\section{Introduction}

The composite material is already widely used in the field of engineering. One of them is the use as a substitute in the construction field. There is now quite a lot of research on composite materials as wood replacement material, but still relies heavily on the availability of the wood itself as a filling material (filler).

Several alternatives have been developed in order to address the growing scarcity of raw materials from nature, with the advantage of technological developments have created a 
derivative of wood products such as particle board, cement board, fiberboard, etc. [1]. This derivative boards made using composite technology where appropriate adhesive, to assist the formation of bonds between fibers are stronger so that the resulting properties of a good board. Particle board is a kind of composite products or wood particles made of particles of wood or other cellulose materials bonded with adhesive [2]. The main ingredient particle board is industrial waste such as sawdust. In addition cellulose materials can also be used as a particle board. One example of research on particle board, as has been done by Sudarsono in the manufacture of particle board made from coconut fiber with natural binder (glue copal) [1]. Sudarsono in his research testing to determine the physical and mechanical properties of particle board [1].

Paper is one of the results of the processed wood is widely used in daily life. Paper is a material that is thin and flat, which is produced by compression of the fiber derived from the pulp. Fiber used is always natural, and contains cellulose and hemicellulose. Natural fibers have gained increased attention because of its internal structure, which can guarantee high porosity. Among these fibers, cellulose is a biopolymer that is the most representative and widely used to produce paper and cardboard [3]

In general, a lot of paper waste thrown away and not used. Waste paper at the present time is still largely seen as a useless waste environment. Paper waste is often piled up in place waste into environmental problems if not treated properly. Hatta in his research utilizing the types of newsprint and cardboard in the processing of waste paper into pulp as the packaging material of agro-products, which in this study aims to get the added value of the packaging materials that have economic value [4].

Trash waste newspaper is one of the waste that often affects the cleanliness and beauty of the surroundings. Therefore, it needs to be an effort to take advantage of waste newspapers that have economic value. The use of old newspapers as a composite material has many advantages. Waste newspapers easily available and cheap. Newsprint is a type of natural fiber, so its use is certainly environmentally friendly and harmless. Material capable of recycled newsprint and is an organic material which can be decomposed by nature. Natural fibers have several advantages, capable of reducing noise, temperature insulation, has a low density and high mechanical capabilities that can be available to industry requirements [57].

The ability of particle board newsprint as a good insulator, can be determined by a series of thermal conductivity testing. An infrared thermometer will be used in temperature measurement, on the side adjacent to heat sources, and on the other side with a predetermined heating time.

\section{Experiments Procedure}

This research is experimental and has three variables, namely the independent variable, the dependent variable and the control variables. The independent variables in this study is the thickness of the particle board, while the dependent variable is the thermal conductivity values of particle board that has been made. The control variables in this study is the mass of paper pulp 450 grams, the mass of adhesive (PVAC) 260 grams, long exposure time 2 minutes, the power of the energy source 100 Watt, drying, particle board for 5 days, and the size of the particle board $(12 \times 7) \mathrm{cm}^{2}$.

The materials used in this study is newsprint, adhesive (PVAC), hot water. Meanwhile, a tool used in this research is particle board printer box, infrared thermometers and lamps with 100 watts.

Newsprint soaked in plain water during the day and night, then limp textured paper soaked in hot water back. Soaking conducted for one hour, stirring frequently, until into pulp. Manufacture of particle board made by mixing the pulp with PVAC adhesive. Adhesives (adhesiv) is a substance that can unite two or more objects through the bonding surface. Gluing is an event attraction between molecules of two bonded surfaces. Taped two objects and bonded it occur by the force of 
attraction between the adhesive material bonded (adhesion) and the attractive force (cohesion) between the adhesive with an adhesive and glued materials [8]. Mix PVAC with pulp and stir it until well blended then put in a mold that has been coated by a plastic sheet. Flatten The mixed material with a spoon so that the board is formed into solid, and adjust the heights or thickness of the particle board by using ruler with varying thickness of $0,5 \mathrm{~cm} ; 1 \mathrm{~cm} ; 1,5 \mathrm{~cm} ; 2 \mathrm{~cm} ; 2,5 \mathrm{~cm}$; $3 \mathrm{~cm}$. The board sheets were already solid and then remove it from the mold and then left overnight in the room so the adhesive can hardening before drying aproximately for 5 days to reduce the water content of the board. Testing of particle boards by measuring the thermal conductivity value of particle board using infrared thermometers, thermal conductivity testing schematic shown in Figure1.

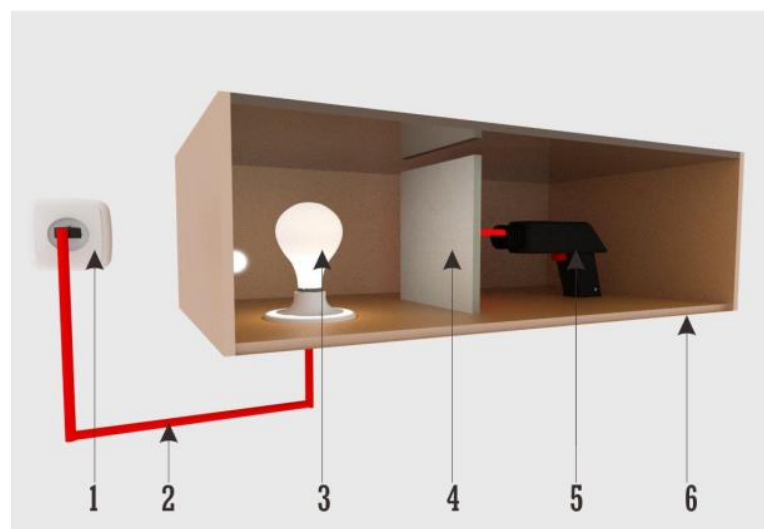

Figure 1. Schematic of modified thermal conductivity testingThe power source

Information:

1. Cables

2. The heat source measurable from heat value

3. The test object (Particle Board Newsprint)

4. The infrared thermometer measuring the temperature of the specimen

5. Box (cardboard)

Set position of thermal energy sources to the test material, Measure initial temperature using an infrared thermometer on the side surface of the particle board before getting a heat source. Measure the other side surface of the particle board from a heat source using an infrared thermometer after 2 minutes, with different particle board thickness.

\section{Result and Discussion}

Insulating properties of a material describes how well the material is in resist heat flow rate [9]. Measurement data obtained directly in the form of sample thickness with a range of $0,5 \mathrm{~cm}$ to $3 \mathrm{~cm}$. Each sample is tested thermal conductivity values. Measurement data obtained by analyzing the data to determine the value of the thermal conductivity of particle board that has been made. $\mathrm{n}$ 1822, Fourier, a French scientist postulate that the speed of heat conductivity per unit cross-sectional area of a material is directly proportional to gradian of temperature that occur within the material. Thermal characterization of samples by defining their thermal conductivity $(\lambda)$ in the mono-dimensional heat flux conditions, so considering a simplified version of the law of Fourier [3]:

$$
\phi=(\lambda / d) A \Delta T
$$

The rate of heat flow on a flat wall can be calculated by integrating the temperature gradient, with thermal conductivity [10], the equation:

$$
\mathrm{q} / \mathrm{A}=-\mathrm{k} \times \mathrm{dT} / \mathrm{dx}
$$

Where $\mathrm{q}$ is the heat flow rate (W), $\mathrm{k}$ is the thermal conductivity of the material $\left(\mathrm{W} / \mathrm{m}^{0} \mathrm{C}\right)$, $A$ is the cross-sectional area $\left(\mathrm{m}^{2}\right), \Delta \mathrm{T}\left(\mathrm{T}_{1}-\mathrm{T}_{2}\right)$ is a wall surface temperature $\left({ }^{\circ} \mathrm{C}\right)$ and $d x$ is the thickness of the wall / material (m). Sign agreement to write the equation of heat in the form of mathematical konduks determined that heat direction perpendicular wall with a distance $\mathrm{L}$ direction of heat flow into a positive. Given according to the second law of thermodynamics, heat will flow automatically from the point to a higher temperature to the point that the lower temperature, the heat flow to be positive when the negative temperature gradient. Accordingly, the basic 
equation for one-dimensional conduction is written:

$$
\mathrm{q}=\mathrm{k} \times \mathrm{A} / \mathrm{L} \times \Delta \mathrm{T}
$$

When the heat source (q) through the test material with a thickness (L) and crosssectional area (A) at a temperature (T), the conductivity of the material can be calculated by the equation:

$$
\mathrm{k}=(\mathrm{q} \times \mathrm{L}) /(\mathrm{A} \times \Delta \mathrm{T})
$$

The thermal conductivity showed the ability of body heat dissipates. The relationship between the thermal conductivity and thickness of different particle board can be seen in Figure 2.

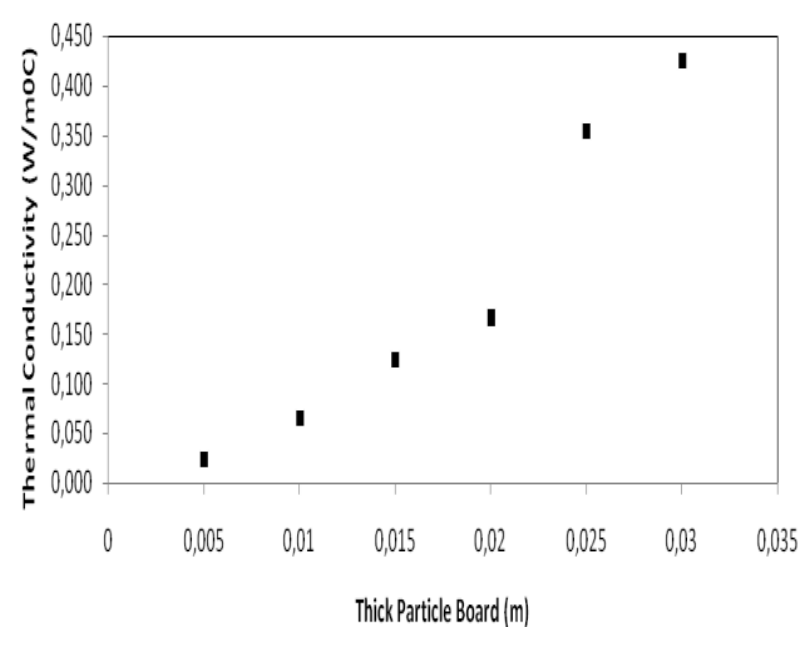

Figure 2. Particle board thickness variation graph paper on thermal conductivity.

Figure 2 shows the value of thermal conductivity at each particle board newsprint based on variations in thickness, the thicker particle board newsprint conductivity values increasingly rising. These results together with the results of research conducted by $\mathrm{H}$. Wibowo, Toto R., and Manarul I., about the effect of the density and thickness of the heat insulation properties of rice husk particle board, which says that the value of thermal conductivity at each rice husk particle board different shows the increasingly thick particle board rice husk conductivity values increasingly rising [11]. Particle board which has a thickness of $0.005 \mathrm{~m}$, has smallest conductivity $0.025 \mathrm{~W} / \mathrm{m}^{\circ} \mathrm{C}$ and greatest conductivity value contained in thickness of $0.03 \mathrm{~m}$ is $0.425 \mathrm{~W} / \mathrm{m}^{\circ} \mathrm{C}$. Good material used as material for heat insulation has a thermal conductivity value of about $0.1 \mathrm{~W} / \mathrm{m}^{\circ} \mathrm{C}$ [11].

Based on the statement, the particle board thickness range of $0,01 \mathrm{~m}$ to $0,02 \mathrm{~m}$ can be categorized as good material used as insulator material with a $\mathrm{k}$ value of $0.066 \mathrm{~W} / \mathrm{m}^{\circ} \mathrm{C} ; 0.125$ $\mathrm{W} / \mathrm{m}^{\circ} \mathrm{C} ; 0.0167 \mathrm{~W} / \mathrm{m}^{0} \mathrm{C}$. Low thermal conductivity due to the low conductivity of the air trapped in the pores [8].

\section{Conclusion}

Based on the research that has been done, it can be seen that the thickness of the particle board newsprint have an impact with the value of thermal conductivity. Lowest thermal conductivity value to $0,005 \mathrm{~m}$ thick board that is $\mathrm{k}=0,025 \mathrm{~W} / \mathrm{m} 0 \mathrm{C}$, the highest conductivity at a thickness of $0,03 \mathrm{~m}$ is $\mathrm{k}=0,425 \mathrm{~W} / \mathrm{m} 0 \mathrm{C}$ The greater thickness, with greater value of thermal conductivity.

\section{Acknowledgement}

Thanks to all those who have helped in this study. Laboratory manager and all those who can not mention one by one.

\section{References}

[1] T.R. Sudarsono, and S. Yogi, Pembuatan Papan Partikel Berbahan Baku Sabut Kelapa dengan Bahan Perekat Alami (Lem Kopal). Jurnal Teknologi, vol 3, no 1, pp. 23- 24, 2010.

[2] T.M. Maloney, Modern Particle Board and Dry Process Fibre Board Manufacturing. Miller Freeman. inc San Fransisco, 1993.

[3] F. Asdrubalia, A.L. Piselloa, F. D'Alessandroa, F. Bianchia, and $M$. Cornicchiaa, C. Fabiania. Innovative cardboard based panels with recycled materials from the packaging industry: thermal and acoustic performance analysis. 6th International Building Physics Conference, 78, pp.321-326, 2015. 
[4] M. Hatta, Pengolahan Kertas Menjadi Pulp sebagai Bahan Pengemas produk Agro industri. Jurusan Teknik Kimia. Prosiding, Palembang, 2011.

[5] J.M. Felix, and P. Gatenholm, The Nature of Adhesion In Composites of Modified Cellulosa Fibers and Polypropylene. Journal of Applied Polymer Science, volume 42, 1991, pp. 609- 620. Karnani, R. Biofiber- Reinforced Polypropylene Composites. Polymer Engineering and Science, vol 37 no 2, pp. 466- 482, 1997.

[6] W.W. Raharjo, Efek Kadar Air pada Sifat Mekanik Komposit Unsaturated Polyester yang diperkuat Serat Cantula. Tesis, 2002.

[7] R. Karnani, Biofiber- Reinforced Polypropylene Composites. Polymer Engineering and Science, vol 37 no 2, pp. 466- 482, 1997.
[8] N. Pratama, D. Djusmaini, dan D. Yenni. Pengaruh Variasi Ukuran Partikel Terhadap Nilai Konduktivitas Termal Papan Partikel Tongkol Jagung. Pillar of Physics, Vol 7, pp.25- 32, 2016.

[9] S. Mulyadi, E. Adril, dan I. Apriono. Uji Isolator Papan Sekam Dengan variasi ukuran partikel dan kepadatan. Jurnal Teknik Mesin, Vol. 7, 2010.

[10] A. Barata, Le Ode. Studi Bahan Isolator Berbahan Dasar Limbah Batubara Bottom Ash. Dinamika Jurnal IlmiahTeknik Mesin. Vol. 7, No. 2, 2016.

[11] H. Wibowo, R. Toto, dan L. Manarul, . Pengaruh Kepadatan dan Ketebalan terhadap Sifat Isolator Panas Papan partikel Sekam Padi. Jurusan Teknologi, Vol. 1, No 2, pp.107-111, 2008. 